\title{
Initial growth of maize in response to application of rock phosphate, vermicompost and endophytic bacteria
}

\author{
Lílian Estrela Borges Baldotto ${ }^{1, *}$; Luiz Gonzaga Jr. Santos Silva ${ }^{2}$; Luciano Pasqualoto Canellas ${ }^{3}$; \\ Fábio Lopes Olivares ${ }^{4}$; Marihus Altoé Baldotto ${ }^{1}$
}

\begin{abstract}
Due to the high energy requirement and demand for non-renewable resources for the production of chemical fertilizers, added also to the environmental impact caused by the use of such products, it is important to intensify research on bio-based agricultural inputs. The use of nitrogen-fixing endophytic and phosphate solubilizing bacteria can provide these nutrients to the plants from the air and poorly soluble phosphorus sources, such as phosphate rock. The objective of this study was to evaluate the nutrition and initial growth of maize (Zea mays L.) in response to the inoculation of nitrogen-fixing and rock phosphate solubilizing endophytic bacteria, in single or mixed formulation, applied with vermicompost. The treatments containing bacteria, both diazotrophic and phosphate solubilizing, when compared to controls, showed higher levels of leaf nitrogen and phosphorus in maize, as well as higher growth characteristics. The application of vermicompost showed synergistic effect when combined with endophytic bacteria. Thus, the innovation of the combination of the studied factors may contribute to the early development of maize.
\end{abstract}

Key words: Zea mays L., plant growth-promoting bacteria, biological nitrogen fixation, phosphate solubilizing bacteria, biological inputs.

\section{RESUMO}

\section{Crescimento inicial do milho em resposta à aplicação de fosfato de rocha, vermicomposto e bactérias endofíticas}

Devido à alta exigência energética e demanda por recursos não renováveis para a produção de fertilizantes químicos, somadas, ainda, ao impacto ambiental provocado pelo uso de tais produtos, é importante a intensificação de pesquisas com insumos agrícolas de base biológica. $\mathrm{O}$ uso de bactérias endofíticas fixadoras de nitrogênio e solubilizadoras de fosfatos pode disponibilizar esses nutrientes para as plantas a partir do ar e de fontes fosfatadas pouco solúveis, como fosfatos de rochas. O objetivo deste trabalho foi avaliar a nutrição e o crescimento inicial de milho (Zea mays L.) em resposta à inoculação de bactérias endofíticas fixadoras de nitrogênio e solubilizadoras de fosfato de rocha, em formulação simples ou mista, aplicadas com vermicomposto. As plantas de milho dos tratamentos contendo bactérias, tanto as diazotróficas quanto as solubilizadoras de fosfato, quando comparadas às do controle, apresentaram maiores teores foliares de nitrogênio e fósforo no milho, acompanhados por características de crescimento mais elevadas. A aplicação de vermicomposto apresentou efeito sinérgico quando combinada com as bactérias endofíticas. Dessa forma, a inovação da combinação dos fatores estudados pode contribuir para o desenvolvimento inicial do milho.

Palavras-chave: Zea mays L., bactérias promotoras de crescimento de plantas, fixação biológica de nitrogênio, bactérias solubilizadoras de fosfatos, insumos biológicos.

Recebido para publicação em 19/10/2010 e aprovado em 06/02/2012

${ }^{1}$ Agronomist Engineers. Doctors Science. Universidade Federal de Viçosa, Campus de Florestal. Rodovia LMG, 818, km 06, 35690-000 Florestal, Minas Gerais, Brazil. lilian.estrela@ufv.br; marihus@ufv*Corresponding author.

${ }^{2}$ Agronomist Engineer. Universidade Estadual do Norte Fluminense Darcy Ribeiro (UENF), Laboratório de Solos do Centro de Ciências e Tecnologias Agropecuárias (CCTA). Av. Alberto Lamego, 2000, 28013-602 Campos dos Goytacazes, Rio de Janeiro, Brazil. lgonzaga.agro@gmail.com

${ }^{3}$ Agronomist Engineer. Doctor Science. Universidade Estadual do Norte Fluminense Darcy Ribeiro (UENF), Laboratório de Solos do Centro de Ciências e Tecnologias Agropecuárias (CCTA). Av. Alberto Lamego, 2000, 28013-602 Campos dos Goytacazes, Rio de Janeiro, Brazil. canellas@uenf.br

${ }^{4}$ Agronomist Engineer. Doctor Science. Universidade Estadual do Norte Fluminense Darcy Ribeiro (UENF), Laboratório de Biologia Celular e Tecidual do Centro de Biociências e Biotecnologia. Av. Alberto Lamego, 2000, 28013-602 Campos dos Goytacazes, Rio de Janeiro, Brazil. fabioliv@uenf.br 


\section{INTRODUCTION}

Under conditions of highly weathered soils, nitrogen $(\mathrm{N})$ and phosphorus $(\mathrm{P})$ are the main limiting nutrients to increase the productivity of most crops, including maize. The use of fertilizers demands high usage of energy for their production, consuming non-renewable resources. Due to the constant transformations of nitrogen in the soil, the criterion for nitrogen fertilization often comes from information about the plant response to the application of increasing $\mathrm{N}$ doses in different soils. These results show that this nutrient is present in concentrations lower than those demanded by crops for optimum yield. Additionally, regarding the P, about $90 \%$ of the analyzes carried out in the Brazilian soils show that the levels of $\mathrm{P}$ available to crops are low and may be below $1 \mathrm{mg} \mathrm{dm}^{-3}$ by the Mehlich-1 extractor, requiring the application of high amounts of this nutrient (Malavolta, 1980).

One way to optimize plant growth and development may be the application of endophytic diazotrophic and phosphate solubilizing bacteria, due to their biofertilizer and biostimulant effects (Vessey, 2003; Bucher \& Reis, 2008; Baldotto el al., 2010a). Variations among genotypes in response to N (Alfoldi et al., 1992) and plant-associated bacteria are known to the maize crop (Salomone \& Döbereiner, 1996). Knowledge on the association between maize and phosphate-solubilizing bacteria is still incipient but promising, since various bacterial genera have demonstrated the ability to solubilize inorganic phosphate compounds in vitro, such as Pseudomonas, Bacillus, Rhizobium, Burkholderia, Achromobacter, Agrobacterium, Microccocus, Flavobacterium, and Erwinia (Rodriguez \& Fraga, 1999).

Although positive results on growth and development of plants have been obtained from diazotrophic bacteria, especially from the genus Azospirillum (Salomone \& Döbereiner, 1996), in Brazil the development of inoculants for the maize crop still requires basic studies. These studies must be based on the selection of species and strains of bacteria that promote plant growth and inoculation technologies associated with plant genotypic variability. The use of nitrogen-fixing and/or rock phosphate solubilizing microorganisms is still a relatively unexplored field and could play an important role in the complementary supply of $\mathrm{N}$ and $\mathrm{P}$ to plants in different agricultural production systems.

The intensification of the use of microorganisms will depend, in parts, on the knowledge of their ecology, their interaction in soil-plant system and insulation and wellconducted microbial selection programs (Okon \& Labandera-Gonzales, 1994). The $\mathrm{N}$ fixation and solubilization of phosphates are considered the most important attributes in the selection process of these growth-promoting microorganisms, directed towards the development of biofertilizers (Pooja-Suneja et al., 2007; Liebich et al., 2007).

However, even if the beneficial effects on plant growth due to inoculation with growth-promoting bacteria are well described, their use in the production environment still has to be accomplished. The carbon source for the microorganism, the adoption of single or mixed formulations (one or more bacteria combined), the strategies of manipulation and activation of the inoculum, and the manner and time of application, as well as the use of suitable vehicles, can become key aspects for the success of this practice (Silva Filho \& Vidor, 2000; Kostov \& Lynch, 1998; Vargas-García et al., 2006).

The present work aimed to study the initial growth and mineral nutrition of maize in response to inoculation of nitrogen fixing and rock phosphate solubilizing endophytic bacteria in single or mixed formulations, in combination with vermicompost.

\section{MATERIALS AND METHODS}

\section{Treatments and experimental conditions}

The experimental matrix consisted of the following factors under study: the bacteria Herbaspirillum seropedicae HIII 206 and Burkholderia sp. UENF 114111, Araxá rock phosphate, vermicompost and two control treatments: one without addition of the factors under study and the other with the application of a NPK formulation (Table 1).

Three seeds of maize, genotype UENF506-8, were planted in $1.0 \mathrm{dm}^{3}$ plastic pots containing a substrate consisting of Plantmax Hortaliças HA. This substrate was chemically characterized (Embrapa , 1997) as presenting: pH 6.9; $76.6 \mathrm{~g} \mathrm{dm}^{-3} \mathrm{OM} ; 12 \mathrm{mg} \mathrm{dm}^{-3} \mathrm{P} ; 14 ; 3 ; 12 ; 0 ; 0 ; 0.1 ; 15$; $15 ; 15 \mathrm{mmol}_{\mathrm{c}} \mathrm{dm}^{-3}$ of $\mathrm{K}, \mathrm{Ca}, \mathrm{Mg}, \mathrm{Al}, \mathrm{H}+\mathrm{Al}, \mathrm{Na}, \mathrm{SB}, \mathrm{T}, \mathrm{t}$, respectively. The vermicompost was produced from cattle manure and filter cake (by-product from the clarification of sugarcane broth) in a 2:1 ratio and Red Californian worms (Eisenia foetida L.) and chemically characterized (Embrapa, 1997) as presenting: $\mathrm{pH} 6.5 ; 87.3 \mathrm{~g} \mathrm{dm}^{-3} \mathrm{OM} ; 2.44 \mathrm{mg} \mathrm{dm}^{-3}$ $\mathrm{P} ; 798 ; 462 ; 26 ; 0 ; 48 ; 10.8 ; 519 ; 567 ; 519 \mathrm{mmol}_{\mathrm{c}} \mathrm{dm}^{-3}$ of K, $\mathrm{Ca}, \mathrm{Mg}, \mathrm{Al}, \mathrm{H}+\mathrm{Al}, \mathrm{Na}, \mathrm{SB}, \mathrm{T}$, t, respectively. The fertilization was based on the recommendations for maize genotype UENF 506-8: $200 \mathrm{mg}$ plant $^{-1}$ of Araxá rock phosphate, $5 \mathrm{~g}$ / plant of vermicompost, $200 \mathrm{mg} / \mathrm{plant}$ of NPK (4-14-8), and applied onto the substrate and around of the crown of the maize seedlings (De-Polli et al., 1988). The pots received daily irrigation and were kept in a greenhouse at Universidade Estadual do Norte Fluminense Darcy Ribeiro, in the municipality of Campos dos Goytacazes, Rio de Janeiro State, Brazil. The experiment was conducted in a completely randomized design with five replicates. 


\section{Bacterial isolates and inoculation}

The bacterial isolate Burkholderia sp. UENF 114111 was derived from the collection of growth-promoting bacteria from the Laboratory of Cell Biology and Tissue from the Universidade Estadual do Norte Fluminense Darcy Ribeiro and has the ability to fix atmospheric N (Santos, 2008) and solubilize rock phosphate (Baldotto et al. 2010b). The isolate of Herbaspirillum seropedicae HIII 206, atmospheric $\mathrm{N}$ fixing, was kindly provided by Dr. Fabio Bueno dos Reis Jr., Embrapa-CPAC (Brasília-DF, Brazil).

The bacterial isolates grew in DYGS liquid medium (Döbereiner et al., 1995) under agitation at $120 \mathrm{rpm}$, at 30 ${ }^{\circ} \mathrm{C}$, for 24 hours. The concentrations of the bacterial suspensions were adjusted to $10^{8}$ cells $\mathrm{mL}^{-1}$.

The inoculation was performed after seed germination; and the plants had about two to three non-fully expanded leaves. The bacterial suspensions were applied to the maize seedlings and on the substrate surface, at the rate of $2 \mathrm{~mL}$ per seedling, around the crown and side-dressed.

\section{Morphological Analysis}

At 30 days after germination, the plants were collected to measure the following variables: number of leaves (NL); plant height $(\mathrm{H})$ as the distance between crown and sheath of the first fully expanded leaf, using a graduated ruler; stem diameter (SD), measured with a Starrett 727 digital caliper; leaf area (LA), measured using a LI-COR LI-3100 Area Meter (LI-COR, USA); root (RFM) and aerial part (SFM) fresh matter; root area (RA), estimated from scanned images by DeltaT Scan image analysis software obtained with a Samsung 5.1 mega pixel digital camera with focal length 0.9 $\mathrm{m}$ in height; root (RDM) and aerial part (SDM) dry matter,

Table 1. Treatment arrangement combining the factors in study

\begin{tabular}{lccccc}
\hline & \multicolumn{5}{c}{ Factors in study } \\
\cline { 2 - 6 } Treatments $^{1}$ & B1 & B2 & V & NP & NPK \\
\hline$(-)$ & 0 & 0 & 0 & 0 & 0 \\
B1 & 1 & 0 & 0 & 0 & 0 \\
B2 & 0 & 1 & 0 & 0 & 0 \\
B1+B2 & 1 & 1 & 0 & 0 & 0 \\
B1+V & 1 & 0 & 1 & 0 & 0 \\
B2+V & 0 & 1 & 1 & 0 & 0 \\
B1+B2+V & 1 & 1 & 1 & 0 & 0 \\
B1+NP & 1 & 0 & 0 & 1 & 0 \\
B2+NP & 0 & 1 & 0 & 1 & 0 \\
B1+B2+NP & 1 & 1 & 0 & 1 & 0 \\
B1+V+NP & 1 & 0 & 1 & 1 & 0 \\
B2+V+NP & 0 & 1 & 1 & 1 & 0 \\
B1+B2+V+NP & 1 & 1 & 1 & 1 & 0 \\
NPK & 0 & 0 & 0 & 0 & 1 \\
\hline
\end{tabular}

${ }^{1}$ Treatments: $(-)=$ control; $\mathrm{B} 1=$ Herbaspirillum seropedicae $\mathrm{HIII}$ 206; B2 = Burkholderia sp., UENF 114111; B1 + B2 = mixed inoculums, with both bacteria; $\mathrm{V}=$ vermicompost; $\mathrm{NP}=$ natural rock phosphate and NPK $=4-14-8$ formula. dried in a forced ventilation oven at $60^{\circ} \mathrm{C}$, for seven days, and weighed; and root/shoot ratio (RSR), obtained by the ratio between the root dry matter and aerial part dry matter.

The SPAD index, which estimates the level of chlorophyll through the green color intensity, was determined using a SPAD-502 portable chlorophyll meter (Minolta, Japan), also at 30 days after germination.

\section{Mineral Nutrition Analysis}

After drying, the maize leaves were ground in a Wiley mill using $0.25 \mathrm{~mm}$ sieves ( $60 \mathrm{mesh}$ ). Then, the ground and sieved material was digested with sulfuric acid combined with hydrogen peroxide. Total $\mathrm{N}$ and $\mathrm{P}$ concentrations $\left(\mathrm{g} . \mathrm{kg}^{-1}\right)$ were determined according to Embrapa (1997). For $\mathrm{N}$, the Nessler method was used; and for $\mathrm{P}$ there was chosen the molecular absorption spectrophotometry (colorimetry) method at a wavelength of $725 \mathrm{~nm}$, after reaction with vitamin $\mathrm{C}$ and ammonium molybdate (Braga \& De Filippo, 1974). The N and P contents (mg/plant) were calculated by multiplying the dry matter of the aerial part by the concentration of the nutrient considered.

\section{Bacterial Count}

Bacteria present in the roots were counted using the Most Probable Number method (MPN), described in Döbereiner et al. (1995). For this, $1 \mathrm{~g}$ of washed root was macerated in $9 \mathrm{~mL}$ of saline solution and serial dilutions were performed up to $10^{-7}$. Then, an aliquot of $0.1 \mathrm{~mL}$ of each dilution was added to vials containing $5 \mathrm{~mL}$ of semi solid culture media JNFb and JMV. The vials were incubated at $30{ }^{\circ} \mathrm{C}$, for seven days. The bacteria counting was estimated by referring to the McCrady's table for three replicates per dilution. It was considered as positive growth the formation of a pellicle on the surface of the medium. The identity of the re-isolated bacteria was confirmed by the characteristics of the colony on the semi-specific media and the cells under the phase contrast microscope (Döbereiner et al., 1995), made from the bacterial growth present in the last dilutions of the semi-solid media.

\section{Statistical analysis}

The results were subjected to analysis of variance, and the effects of the treatments were unfolded in mean contrasts (Table 2), according to Alvarez V. \& Alvarez (2006). The application of the F test to the unfolding of the factors was performed at 5 and $1 \%$ of probability.

\section{RESULTS}

Tables 3 and 4 show the means for the characteristics of growth and dry matter accumulation, contents of $\mathrm{N}$ and $\mathrm{P}$ and also the data on bacteria recovery from the maize plants. Using these means, the mean contrasts were calculated, which indicates the difference, in actual magnitude and unit, 
between the mean of the compared groups; that is, the effect of these comparisons (Tables 5 and 6).

In the first contrast presented in Table 5, for example, the use of bacteria (alone) compared with the control treatment (non-inoculated plants) resulted in an increase of approximately $30 \%$ in dry matter of the aerial part. Following this procedure, still in Table 5, positive effects of bacteria can be observed on the variable number of leaves, plant height, stem diameter, leaf area, fresh matter of aerial part, root fresh matter, root area and root/shoot ratio, which were $6,11,9,29,59,45,128$ and $22 \%$ respectively. Similarly, Table 6 shows the positive effects of the application of bacterial inoculums on the SPAD index and contents of $\mathrm{N}$ and $\mathrm{P}$ in the maize plants of 28, 10, 59,103 and $41 \%$ respectively.

The second contrast in Tables 5 and 6 highlights the comparison between the NPK fertilization and the application of bacterial inoculum (also used alone). The NPK fertilization was superior to the application of bacteria for all variables of the aerial part and the nutritional status. The opposite was observed for the variables of the root system.

The effect of vermicompost in combination with bacterial inoculums, in the third contrast (Tables 5 and 6), was unfavorable to most of the growth characteristics of the plants, although it resulted in an improvement of the nutritional status, especially in relation to $\mathrm{N}$ content. Then, in the fourth contrast, it was observed that the application of natural rock phosphate to bacteria had little effect on the growth characteristics, even though there was improvement in the nutritional composition. The combination of bacteria with vermicompost and natural phosphate resulted in root growth decrease and increase in nutrient absorption (fifth contrast in Tables 5 and 6).

Both species of bacteria used in the experiment were compared in the sixth contrast in Tables 5 and 6. It was found that the application of Burkholderia sp. resulted in improvement in root system characteristics in comparison with Herbaspirillum seropedicae. However, no significant differences in the growth characteristics of the shoot or nutritional status were observed. The three contrasts that followed compare these bacteria within the factors vermicompost and natural rock phosphate, as well as their combination. Little difference was observed between the bacteria, but the resulting $\mathrm{N}$ content when comparing these two inoculums combined with vermicompost and natural phosphate is noteworthy, with a strong decrease in absorption and accumulation of this nutrient in the treatment with Burkholderia sp. compared with Herbaspirillum seropedicae (Table 6).

The $10^{\text {th }}, 11^{\text {th }}$ and $12^{\text {th }}$ contrasts of Tables 5 and 6 aimed to compare the effect of inoculum of each bacterium alone with its combination; that is, with the mixed inoculum, with or without vermicompost and natural phosphate. Small differences were observed in the growth data for the comparison in the absence of vermicompost and natural rock phosphate, and even in the presence of the last factor being studied. However, the mixed inoculum combined with vermicompost stood out among the treatments. Both plant growth and nutritional status were improved significantly when bacteria were applied together (mixed inoculum) and with vermicompost. As it has been already shown, the use

Table 2. Coefficients for the contrasts used to unfold the effects of the treatments

\begin{tabular}{|c|c|c|c|c|c|c|c|c|c|c|c|c|c|}
\hline \multirow{2}{*}{ Treatments ${ }^{1}$} & \multicolumn{13}{|c|}{ Contrasts $^{2}$} \\
\hline & $\mathrm{C}_{1}$ & $\mathrm{C}_{2}$ & $\mathrm{C}_{3}$ & $\mathrm{C}_{4}$ & $\mathrm{C}_{5}$ & $\mathrm{C}_{6}$ & $\mathrm{C}_{7}$ & $\mathrm{C}_{8}$ & $\mathrm{C}_{9}$ & $\mathrm{C}_{10}$ & $\mathrm{C}_{11}$ & $\mathrm{C}_{12}$ & $\mathrm{C}_{13}$ \\
\hline$\overline{(-)}$ & -12 & 0 & 0 & 0 & 0 & 0 & 0 & 0 & 0 & 0 & 0 & 0 & 0 \\
\hline B1 & 1 & 1 & -1 & -1 & -1 & -1 & 0 & 0 & 0 & -1 & 0 & 0 & 0 \\
\hline B2 & 1 & 1 & -1 & -1 & -1 & 1 & 0 & 0 & 0 & -1 & 0 & 0 & 0 \\
\hline $\mathrm{B} 1+\mathrm{B} 2$ & 1 & 1 & -1 & -1 & -1 & 0 & 0 & 0 & 0 & 2 & 0 & 0 & 0 \\
\hline $\mathrm{B} 1+\mathrm{V}$ & 1 & 1 & 1 & 0 & 0 & 0 & -1 & 0 & 0 & 0 & -1 & 0 & 0 \\
\hline $\mathrm{B} 2+\mathrm{V}$ & 1 & 1 & 1 & 0 & 0 & 0 & 1 & 0 & 0 & 0 & -1 & 0 & 0 \\
\hline $\mathrm{B} 1+\mathrm{B} 2+\mathrm{V}$ & 1 & 1 & 1 & 0 & 0 & 0 & 0 & 0 & 0 & 0 & 2 & 0 & 0 \\
\hline $\mathrm{B} 1+\mathrm{NP}$ & 1 & 1 & 0 & 1 & 0 & 0 & 0 & -1 & 0 & 0 & 0 & -1 & 0 \\
\hline $\mathrm{B} 2+\mathrm{NP}$ & 1 & 1 & 0 & 1 & 0 & 0 & 0 & 1 & 0 & 0 & 0 & -1 & 0 \\
\hline $\mathrm{B} 1+\mathrm{B} 2+\mathrm{NP}$ & 1 & 1 & 0 & 1 & 0 & 0 & 0 & 0 & 0 & 0 & 0 & 2 & 0 \\
\hline $\mathrm{B} 1+\mathrm{V}+\mathrm{NP}$ & 1 & 1 & 0 & 0 & 1 & 0 & 0 & 0 & -1 & 0 & 0 & 0 & -1 \\
\hline $\mathrm{B} 2+\mathrm{V}+\mathrm{NP}$ & 1 & 1 & 0 & 0 & 1 & 0 & 0 & 0 & 1 & 0 & 0 & 0 & -1 \\
\hline $\mathrm{B} 1+\mathrm{B} 2+\mathrm{V}+\mathrm{NP}$ & 1 & 1 & 0 & 0 & 1 & 0 & 0 & 0 & 0 & 0 & 0 & 0 & 2 \\
\hline NPK & 0 & -12 & 0 & 0 & 0 & 0 & 0 & 0 & 0 & 0 & 0 & 0 & 0 \\
\hline
\end{tabular}

${ }^{1}$ Treatments: $(-)=$ control; B1 = Herbaspirillum seropedicae, HIII 206; B2 = Burkholderia sp., UENF 114111; B = single inoculum, with each bacterium used alone; B1 $+\mathrm{B} 2=$ mixed inoculums, with both bacteria; $\mathrm{V}=$ vermicompost; NP = natural rock phosphate, NPK $=4-$ 14-8 formula.

${ }^{2}$ Contrasts: $\mathrm{C}_{1}=(-)$ vs. $\mathrm{B} ; \mathrm{C}_{2}=\mathrm{NPK}$ vs. $\mathrm{B} ; \mathrm{C}_{3}=\mathrm{B}$ vs. $\mathrm{B}+\mathrm{V} ; \mathrm{C}_{4}=\mathrm{B}$ vs. $\mathrm{B}+\mathrm{NP} ; \mathrm{C}_{5}=\mathrm{B}$ vs. $\mathrm{B}+\mathrm{V}+\mathrm{NP} ; \mathrm{C}_{6}=\mathrm{B} 1$ vs. $\mathrm{B} 2 ; \mathrm{C}_{7}=\mathrm{B} 1$ vs. $\mathrm{B} 2 \mathrm{~d} / \mathrm{V} ; \mathrm{C}_{8}=$ $\mathrm{B} 1$ vs. $\mathrm{B} 2 \mathrm{~d} / \mathrm{NP} ; \mathrm{C}_{9}=\mathrm{B} 1$ vs. $\mathrm{B} 2 \mathrm{~d} / \mathrm{V}+\mathrm{NP} ; \mathrm{C}_{10}=\mathrm{B}$ vs. $\mathrm{B} 1+\mathrm{B} 2 ; \mathrm{C}_{11}=\mathrm{B}$ vs. B1+B2 d/ V; $\mathrm{C}_{12}=\mathrm{B}$ vs. B1+B2 d/ NP and C $13=\mathrm{B}$ vs. B1+B2 d/ V+NP. 
of natural rock phosphate improved only slightly the effect of the mixed inoculum on plant growth and nutrition; however, in combination with vermicompost, there was also improvement in such effect, although it was diluted when comparing the use of vermicompost alone with the two bacteria combined.
The data on bacteria recovery from the maize plants (Table 4) showed that they harbor in their roots native diazotrophic bacteria with a population of around $2.5 \times 10^{4}$ bacteria $\mathrm{g} /$ root and that the inoculated bacteria were recovered from the different treatments based on their reisolation and identification of culture conditions. The

Table 3. Growth characteristics of maize plants (mean of five replicates) in response to application of natural rock phosphate, vermicompost and endophytic bacteria

\begin{tabular}{|c|c|c|c|c|c|c|c|c|c|c|}
\hline \multirow[b]{2}{*}{ Treatments ${ }^{1}$} & \multicolumn{10}{|c|}{ Growth characteristics ${ }^{2}$} \\
\hline & NL & $\begin{array}{c}\mathbf{H} \\
\mathrm{cm}\end{array}$ & $\begin{array}{l}\text { SD } \\
\mathbf{m m}\end{array}$ & $\begin{array}{c}\mathbf{L A} \\
\mathbf{c m}^{2}\end{array}$ & SFM & $\begin{array}{r}\text { SDM } \\
\end{array}$ & RFM & RDM & $\begin{array}{c}\text { RA } \\
\%\end{array}$ & $\mathbf{R} / \mathrm{S}$ \\
\hline$(-)$ & 8 & 21.70 & 7.84 & 431.58 & 10.42 & 2.48 & 5.62 & 0.63 & 354 & 0.26 \\
\hline B1 & 8 & 23.10 & 9.01 & 552.02 & 16.61 & 3.17 & 6.60 & 0.59 & 198 & 0.19 \\
\hline B2 & 9 & 24.50 & 9.05 & 565.41 & 18.12 & 3.22 & 8.54 & 0.87 & 189 & 0.28 \\
\hline $\mathrm{B} 1+\mathrm{B} 2$ & 9 & 25.10 & 8.08 & 551.62 & 15.93 & 2.93 & 10.18 & 0.63 & 150 & 0.22 \\
\hline $\mathrm{B} 1+\mathrm{V}$ & 8 & 22.70 & 7.71 & 474.75 & 12.56 & 2.81 & 8.22 & 0.64 & 208 & 0.24 \\
\hline $\mathrm{B} 2+\mathrm{V}$ & 8 & 22.40 & 7.77 & 448.44 & 11.46 & 2.57 & 7.26 & 0.44 & 155 & 0.17 \\
\hline $\mathrm{B} 1+\mathrm{B} 2+\mathrm{V}$ & 9 & 26.90 & 8.88 & 661.95 & 21.22 & 4.06 & 8.24 & 0.62 & 154 & 0.16 \\
\hline $\mathrm{B} 1+\mathrm{NP}$ & 8 & 22.50 & 8.66 & 555.27 & 15.67 & 3.39 & 9.33 & 0.72 & 136 & 0.22 \\
\hline $\mathrm{B} 2+\mathrm{NP}$ & 8 & 23.40 & 8.51 & 611.07 & 18.18 & 2.86 & 8.96 & 0.70 & 140 & 0.26 \\
\hline $\mathrm{B} 1+\mathrm{B} 2+\mathrm{NP}$ & 9 & 26.40 & 8.38 & 644.86 & 19.78 & 3.82 & 8.60 & 0.61 & 126 & 0.17 \\
\hline $\mathrm{B} 1+\mathrm{V}+\mathrm{NP}$ & 9 & 25.20 & 9.00 & 619.46 & 19.01 & 3.78 & 7.61 & 0.51 & 105 & 0.14 \\
\hline $\mathrm{B} 2+\mathrm{V}+\mathrm{NP}$ & 9 & 22.80 & 9.00 & 533.78 & 16.64 & 3.02 & 7.63 & 0.53 & 100 & 0.18 \\
\hline $\mathrm{B} 1+\mathrm{B} 2+\mathrm{V}+\mathrm{NP}$ & 8 & 23.60 & 8.07 & 459.92 & 13.75 & 2.59 & 6.37 & 0.54 & 203 & 0.20 \\
\hline NPK & 9 & 26.70 & 10.37 & 689.19 & 26.58 & 4.23 & 6.05 & 0.56 & 106 & 0.14 \\
\hline
\end{tabular}

${ }^{1}$ Treatments: $(-)=$ control; B1 = Herbaspirillum seropedicae, HIII 206; B2 = Burkholderia sp., UENF 114111; B1 + B2 = mixed inoculum, with both bacteria; $\mathrm{V}=$ vermicompost, $\mathrm{NP}=$ natural rock phosphate, $\mathrm{NPK}=4-14-8$ formula.

${ }^{2}$ Growth characteristics: $\mathrm{NL}=$ number of leaves; $\mathrm{H}=$ plant height; $\mathrm{SD}=$ stem diameter; $\mathrm{LA}=$ leaf area; $\mathrm{SFM}=$ fresh matter of aerial part; $\mathrm{SDM}=$ dry matter of aerial part; RFM = root fresh matter; DRM = dry root matter; RA = root area; R/S = root/aerial part ratio.

Table 4. Nutritional characteristics (average of five replicates) of maize plants and bacterial count (average of three replicates) in response to application of natural rock phosphate, vermicompost and endophytic bacteria.

\begin{tabular}{|c|c|c|c|c|c|c|}
\hline \multirow{3}{*}{ Treatments $^{1}$} & \multicolumn{5}{|c|}{ Nutritional charcacteristics ${ }^{2}$} & \multirow{3}{*}{$\begin{array}{c}\text { MPN } \\
g^{(3)} \\
\mathbf{n}^{\circ} \text { cells } \mathbf{g} \text { of } \text { root }^{-1}\end{array}$} \\
\hline & \multirow[b]{2}{*}{ SPAD } & N level & \multirow{2}{*}{ P level } & \multirow{2}{*}{ N Content } & \multirow{2}{*}{$\begin{array}{l}\text { P Content } \\
\text { ant }\end{array}$} & \\
\hline & & & & & & \\
\hline$(-)$ & 20.16 & 18.64 & 6.58 & 47.06 & 16.38 & $4.40 \pm 0.00$ \\
\hline B1 & 23.00 & 22.17 & 6.81 & 69.38 & 21.62 & $5.03 \pm 0.37$ \\
\hline B2 & 24.52 & 23.73 & 7.10 & 76.56 & 23.01 & $4.40 \pm 0.00$ \\
\hline $\mathrm{B} 1+\mathrm{B} 2$ & 25.52 & 26.94 & 7.23 & 80.76 & 21.27 & $6.98 \pm 0.00$ \\
\hline $\mathrm{B} 1+\mathrm{V}$ & 20.84 & 22.54 & 7.13 & 70.97 & 19.90 & $5.98 \pm 0.00$ \\
\hline $\mathrm{B} 2+\mathrm{V}$ & 22.68 & 24.36 & 7.06 & 64.53 & 18.43 & $5.65 \pm 0.00$ \\
\hline $\mathrm{B} 1+\mathrm{B} 2+\mathrm{V}$ & 29.60 & 41.55 & 7.28 & 157.76 & 30.27 & $6.40 \pm 0.00$ \\
\hline $\mathrm{B} 1+\mathrm{NP}$ & 24.88 & 31.17 & 7.21 & 100.61 & 24.25 & $4.40 \pm 0.00$ \\
\hline $\mathrm{B} 2+\mathrm{NP}$ & 28.08 & 37.63 & 7.68 & 108.08 & 21.41 & $4.40 \pm 0.00$ \\
\hline $\mathrm{B} 1+\mathrm{B} 2+\mathrm{NP}$ & 28.78 & 32.93 & 7.16 & 128.27 & 27.06 & $6.48 \pm 0.50$ \\
\hline $\mathrm{B} 1+\mathrm{V}+\mathrm{NP}$ & 28.78 & 34.89 & 7.21 & 129.79 & 27.92 & $6.29 \pm 0.11$ \\
\hline $\mathrm{B} 2+\mathrm{V}+\mathrm{NP}$ & 26.46 & 27.98 & 7.36 & 85.81 & 22.13 & $6.19 \pm 0.21$ \\
\hline $\mathrm{B} 1+\mathrm{B} 2+\mathrm{V}+\mathrm{NP}$ & 25.78 & 29.67 & 7.86 & 75.21 & 20.58 & $6.40 \pm 0.00$ \\
\hline NPK & 32.30 & 46.91 & 9.90 & 187.84 & 42.14 & $4.40 \pm 0.00$ \\
\hline
\end{tabular}

${ }^{1}$ Treatments: $(-)=$ control; B1 = Herbaspirillum seropedicae, HIII 206; B2 = Burkholderia sp., UENF 114111; B1 + B2 = mixed inoculum, with both bacteria; $\mathrm{V}=$ vermicompost, $\mathrm{NP}=$ natural rock phosphate, $\mathrm{NPK}=4-14-8$ formula.

${ }^{2}$ Growth characteristics: $\mathrm{NL}=$ number of leaves; $\mathrm{H}=$ plant height; $\mathrm{SD}=$ stem diameter; $\mathrm{LA}=$ leaf area; $\mathrm{SFM}=$ fresh matter of aerial part; $\mathrm{SDM}=$ dry matter of aerial part; RFM = root fresh matter; $\mathrm{DRM}=$ dry root matter; $\mathrm{RA}=$ root area; $\mathrm{R} / \mathrm{S}=$ root/aerial part ratio.

${ }^{3}$ MPN: most probable number of diazotrophic bacteria.

Rev. Ceres, Viçosa, v. 59, n.2, p. 262-270, mar/abr, 2012 
Table 5. Mean contrasts for root and aerial part growth rates of maize

\begin{tabular}{|c|c|c|c|c|c|c|c|c|c|c|c|c|}
\hline \multirow[b]{2}{*}{ Contrast } & \multirow[b]{2}{*}{ SV. ${ }^{1}$} & \multirow[b]{2}{*}{ D. F. } & \multicolumn{10}{|c|}{ Mean Contrasts ${ }^{2}$} \\
\hline & & & $\mathbf{L N}$ & $\begin{array}{l}\text { PH } \\
\text { cm }\end{array}$ & $\begin{array}{l}\text { SD } \\
\text { mm }\end{array}$ & $\begin{array}{r}\text { FA } \\
\mathbf{c m}^{2}\end{array}$ & SFM & SDM & RFM & RDM & $\begin{array}{r}\text { RA } \\
\%\end{array}$ & $\mathbf{R} / \mathbf{S}$ \\
\hline $\mathrm{C}_{1}$ & (-) vs. B & 1 & $0.52 * *$ & $2.35 * *$ & $0.67 * *$ & $124.97 * *$ & $6.15^{* *}$ & $0.70 * *$ & $2.51 * *$ & -0.01 & $-198.20 * *$ & $-0.06 * *$ \\
\hline $\mathrm{C}_{2}$ & NPK vs. B & 1 & $-0.68 * *$ & $-2.65 * *$ & $-1.86 * *$ & $-132.64 * *$ & $-10.01 * *$ & $-1.05^{* *}$ & $2.08 * *$ & 0.05 & $49.17 * *$ & $0.06^{* *}$ \\
\hline $\mathrm{C}_{3}$ & B vs. $\mathrm{B}+\mathrm{V}$ & 1 & -0.20 & -0.23 & $-0.59 * *$ & -27.97 & -1.81 & 0.04 & -0.53 & $-0.13^{* *}$ & -6.36 & $-0.04 * *$ \\
\hline $\mathrm{C}_{4}$ & B vs. B+NP & 1 & 0.07 & 0.00 & 0.23 & 73.14 & 2.34 & 0.37 & -0.02 & -0.04 & $-48.42 * *$ & -0.03 \\
\hline $\mathrm{C}_{5}$ & $\mathrm{~B}$ vs. $\mathrm{B}+\mathrm{V}+\mathrm{NP}$ & 1 & -0.07 & -0.37 & -0.02 & -18.63 & -0.42 & 0.02 & $-1.24 * *$ & $-0.17 * *$ & $-42.59 * *$ & $-0.05 * *$ \\
\hline $\mathrm{C}_{6}$ & B1 vs. B2 & 1 & 0.40 & 1.40 & 0.04 & 13.39 & 1.51 & 0.04 & $1.95^{* *}$ & $0.28^{* *}$ & -9.47 & $0.10^{* *}$ \\
\hline $\mathrm{C}_{7}$ & B1 vs. B2 d/ V & 1 & 0.40 & -0.30 & 0.06 & -26.31 & -1.10 & -0.24 & -0.96 & $-0.20 * *$ & $-53.08 * *$ & $-0.07 * *$ \\
\hline $\mathrm{C}_{8}$ & B1 vs. B2 d/ NP & 1 & 0.20 & 0.90 & -0.15 & 55.80 & 2.51 & -0.53 & -0.38 & -0.03 & 4.63 & 0.04 \\
\hline $\mathrm{C}_{9}$ & B1 vs. B 2 d/ V+NP & 1 & 0.20 & $-2.40 * *$ & 0.00 & -85.67 & -2.37 & $-0.76^{*}$ & 0.01 & 0.03 & -5.41 & 0.04 \\
\hline $\mathrm{C}_{10}$ & B vs. B1+B2 & 1 & 0.00 & 1.30 & $-0.95 * *$ & -7.09 & -1.44 & -0.27 & $2.61 * *$ & $-0.11 *$ & $-43.28 * *$ & -0.02 \\
\hline $\mathrm{C}_{11}$ & $\mathrm{~B}$ vs. $\mathrm{B} 1+\mathrm{B} 2 \mathrm{~d} / \mathrm{V}$ & 1 & $0.60 * *$ & $4.35 * *$ & $1.14 * *$ & $200.36 * *$ & $9.21 * *$ & $1.37 * *$ & 0.51 & 0.08 & $-27.49 *$ & $-0.05^{*}$ \\
\hline $\mathrm{C}_{12}$ & B vs. B1+B2 d/ NP & 1 & $0.70 * *$ & $3.45 * *$ & -0.21 & 61.69 & 2.85 & $0.69 *$ & -0.54 & -0.10 & -12.39 & $-0.07 * *$ \\
\hline $\mathrm{C}_{13}$ & $\mathrm{~B}$ vs. $\mathrm{B} 1+\mathrm{B} 2 \mathrm{~d} / \mathrm{V}+\mathrm{NP}$ & 1 & $-0.50 * *$ & -0.40 & $-0.92 * *$ & $-116.70 * *$ & $-4.08 * *$ & $-0.81 * *$ & -1.25 & 0.02 & $100.76 * *$ & $0.04 *$ \\
\hline Residue & 56 & 0.41 & 4.90 & 0.96 & 10067.51 & 19.77 & 0.73 & 2.96 & 0.02 & 5.01 & 0.003 & \\
\hline V.C. $(\%)$ & & 7.48 & 9.20 & 11.37 & 18.01 & 26.39 & 26.65 & 22.06 & 23.06 & 28.66 & 25.21 & \\
\hline
\end{tabular}

${ }^{1}$ Sources of Variation: $(-)=$ control; B1 = Herbaspirillum seropedicae, HIII 206, B2 = Burkholderia sp. UENF 114111; B = single inoculum, with each bacterium used alone; B1 + B2 = mixed inoculums, with both bacteria; $\mathrm{V}=$ vermicompost, $\mathrm{NP}=\mathrm{natur}$

${ }^{2}$ Mean Contrasts: $\mathrm{NL}=$ number of leaves; $\mathrm{H}=$ plant height; $\mathrm{SD}=$ stem diameter; $\mathrm{LA}=$ leaf area; $\mathrm{SFM}=$ fresh matter of aerial part; SDM = dry matter of aerial part; RFM = root fresh matter; RDM = root dry matter; $\mathrm{RA}=$ root area; $\mathrm{R} / \mathrm{S}=$ root/aerial part ratio. $* *, *=$ Significant by test $\mathrm{F}$ at 1 and $5 \%$ of probability, respectively. 
inoculation promoted increases in the population associated with the roots varying between zero and $7 \times 10^{2}$.

\section{DISCUSSION}

Among all the treatments, the fertilization with NPK resulted in the best initial development of the maize plants in relation to the other factors studied. However, this superiority measured in absolute terms does not internalize environmental costs of fertilizer manufacturing. The findings of this study showed the possibility of using biofertilizers produced from natural rock phosphate and vermicompost with the addition of $\mathrm{N}$-fixing and phosphate solubilizing bacteria in the initial growth of maize. Positive effects of bacterial inoculation on the growth of aerial parts and roots of maize have been observed, as well as an improvement in their nutritional status.

In a study involving the selection of diazotrophic bacteria, Baldotto et al. (2010b) found that many of them also solubilized $\mathrm{Zn}$ and $\mathrm{P}$ from sources poorly available to plants and synthesized indole (auxins). They also observed that these bacteria increased the growth of aerial parts and roots and the levels of macronutrients in pineapple. In this study, the increase in the initial growth of maize promoted by Herbaspirillum and Burkholderia were also associated with higher nutrient contents, of $\mathrm{N}$ and $\mathrm{P}$, because of their capacity for diazotrophy and phosphate solubilization. Baldotto et al. (2010a) used this same strain of Burkholderia, in combination or not with humified organic matter, and noted an increase in its population in pineapple, which showed greater development of roots and shoots, as well as higher contents of macronutrients.

Among the plants treated with bacteria, those with the highest bacterial recovery also showed the best initial performance, with the highest growth rates, dry matter accumulation and nutrient concentration. The dual inoculation and the vermicompost application are the factors that most contributed to the increase in population of diazotrophic microorganisms in the present experiment, with increases of up to two log units. The sole application of rock phosphate or Burkholderia were the treatments that provided the smallest populations established in the root tissue, even though they were higher than the control. The fact that inoculated plants enhance their population of bacteria, especially when used together with vermicompost, has been previously reported in sugarcane and maize when in combination with humic acids (Marques Jr et al., 2008; Conceição et al., 2008).

Taken together, data on both growth and nutritional characteristics indicate the viability of the two forms of bacterial inoculation (single and mixed). The viability of the mixed inoculum, i.e., the complementary and synergistic interaction of these bacteria in the presence of vermicompost, confirms the hypothesis of joint use of the studied factors in the composition of a biofertilizer with positive effects on nutrition with $\mathrm{N}$ and $\mathrm{P}$, resulting in inoculated plants with superior initial performance

Table 6. Mean contrasts for nutritional indices of maize

\begin{tabular}{|c|c|c|c|c|c|c|c|}
\hline \multirow{4}{*}{$\begin{array}{l}\text { Contrasts } \\
\mathrm{C}_{1}\end{array}$} & \multirow{4}{*}{$\begin{array}{c}\text { S.V. }{ }^{1} \\
\text { (-) vs. B }\end{array}$} & \multirow{4}{*}{$\begin{array}{r}\text { F.D. } \\
1\end{array}$} & \multicolumn{4}{|c|}{ Means contrasts $^{2}$} & \\
\hline & & & \multirow{3}{*}{$\begin{array}{r}\text { SPAD } \\
5.58 * *\end{array}$} & \multirow{3}{*}{$\begin{array}{r}\text { N level } \\
\mathbf{g ~ k g}^{-1}\end{array}$} & \multirow{3}{*}{$\begin{array}{r}\text { P level } \\
0.68 * *\end{array}$} & \multicolumn{2}{|c|}{ N Content P Content } \\
\hline & & & & & & & \\
\hline & & & & & & $48.59 * *$ & $6.78 * *$ \\
\hline $\mathrm{C}_{2}$ & NPK vs. B & 1 & $-6.56 * *$ & $-17.28 * *$ & $-2.64 * *$ & $-92.19 * *$ & $-18.98 * *$ \\
\hline $\mathrm{C}_{3}$ & B vs. B+V & 1 & 0.03 & 5.20 & $0.11 *$ & $22.18 * *$ & 0.90 \\
\hline $\mathrm{C}_{4}$ & $\mathrm{~B}$ vs. $\mathrm{B}+\mathrm{NP}$ & 1 & $3.62 * *$ & 9.51 & $0.19 * *$ & $36.22 * *$ & 2.85 \\
\hline $\mathrm{C}_{5}$ & $\mathrm{~B}$ vs. $\mathrm{B}+\mathrm{V}+\mathrm{NP}$ & 1 & $2.66 * *$ & 6.57 & $0.43 * *$ & $21.37 * *$ & 1.57 \\
\hline $\mathrm{C}_{6}$ & B1 vs. B2 & 1 & 1.52 & 1.57 & 0.29 & 7.18 & 1.39 \\
\hline $\mathrm{C}_{7}$ & B1 vs. B2 d/ V & 1 & 1.84 & 1.82 & -0.08 & -6.44 & -1.47 \\
\hline $\mathrm{C}_{8}$ & B1 vs. B2 d/ NP & 1 & 3.20 & 6.47 & 0.47 & 7.47 & -2.83 \\
\hline $\mathrm{C}_{9}$ & $\mathrm{~B} 1$ vs. $\mathrm{B} 2 \mathrm{~d} / \mathrm{V}+\mathrm{NP}$ & 1 & -2.32 & -6.91 & 0.15 & $-43.98 * *$ & -5.79 \\
\hline $\mathrm{C}_{10}$ & B vs. B1+B2 & 1 & 1.76 & 3.99 & 0.27 & 7.79 & -1.05 \\
\hline $\mathrm{C}_{11}$ & $\mathrm{~B}$ vs. $\mathrm{B} 1+\mathrm{B} 2 \mathrm{~d} / \mathrm{V}$ & 1 & $7.84 * *$ & 18.11 & $0.18^{* *}$ & $90.01 * *$ & $11.11 * *$ \\
\hline $\mathrm{C}_{12}$ & B vs. B1+B2 d/ NP & 1 & 2.30 & -1.47 & -0.29 & 23.92 & 4.23 \\
\hline $\mathrm{C}_{13}$ & B vs. B1+B 2 d/ V+NP & 1 & -1.84 & -1.76 & 0.57 & $-32.59 * *$ & -4.45 \\
\hline Residue & & 56 & 17.95 & 9.8 & 84.23 & 1.211 .17 & 63.14 \\
\hline C.V. $(\%)$ & & & 16.41 & 13.4 & 30.51 & 35.24 & 33.07 \\
\hline
\end{tabular}

${ }^{1}$ Sources of Variation: $(-)=$ control; B1 = Herbaspirillum seropedicae, HIII 206, B2 = Burkholderia sp. UENF 114111, B = single inoculum, with each bacterium used alone; $\mathrm{B} 1+\mathrm{B} 2=$ mixed inoculums, with both bacteria; $\mathrm{V}=$ vermicompost, NP = natural rock phosphate, NPK = 4-14-8 formula.

${ }^{2}$ Mean Contrasts: SPAD = chlorophyll level; $\mathrm{N}$ level = leaf $\mathrm{N}$ level; $\mathrm{P}$ level = leaf $\mathrm{P}$ level; $\mathrm{N}$ content = leaf $\mathrm{N}$ content; $\mathrm{P}$ content = leaf $\mathrm{P}$ content. $* *, *=$ Significant by test $\mathrm{F}$ at 1 and $5 \%$ of probability, respectively. 
and better capacity for subsequent growth, measured as increase in reserves (dry matter), and with consequences in capturing water, light and nutrients (greater growth of shoots and roots). It is inferred that the use of vermicompost, not only as a conditioner of soil fertility, but also as an appropriate vehicle to maintain the activity of bacteria in the environment, constitutes an interesting and suitable strategy, especially given the difficulty of maintaining the inoculum live long enough for its penetration into the plant. The presence of enriched vermicompost with a source of $\mathrm{P}$ seems to preserve the viability of the inoculum, favoring the colonization of the maize plants. Because the organic matter has acidic groups, which increase the solubility of calcium rock phosphates, such as Araxá (Baldotto et al., 2011), the use of this phosphorus source in its natural form seems to be a technical option for production of biofertilizers.

Another finding verified in this study was the relationship between SPAD index and level and content of N (Figure 1). Other studies have shown similarities between these variables. According to Girardini et al, (1985) and Guimarães et al. (1999), it has been shown that the concentration of chlorophyll can indicate the nutritional status of $\mathrm{N}$ in maize. These authors emphasize the use of the SPAD as an auxiliary field tool for estimating the nutritional status of plants. The results of this study indicated that the increases in the levels of $\mathrm{N}$ in maize plants treated with growth-promoting bacteria can also be monitored by the SPAD index.

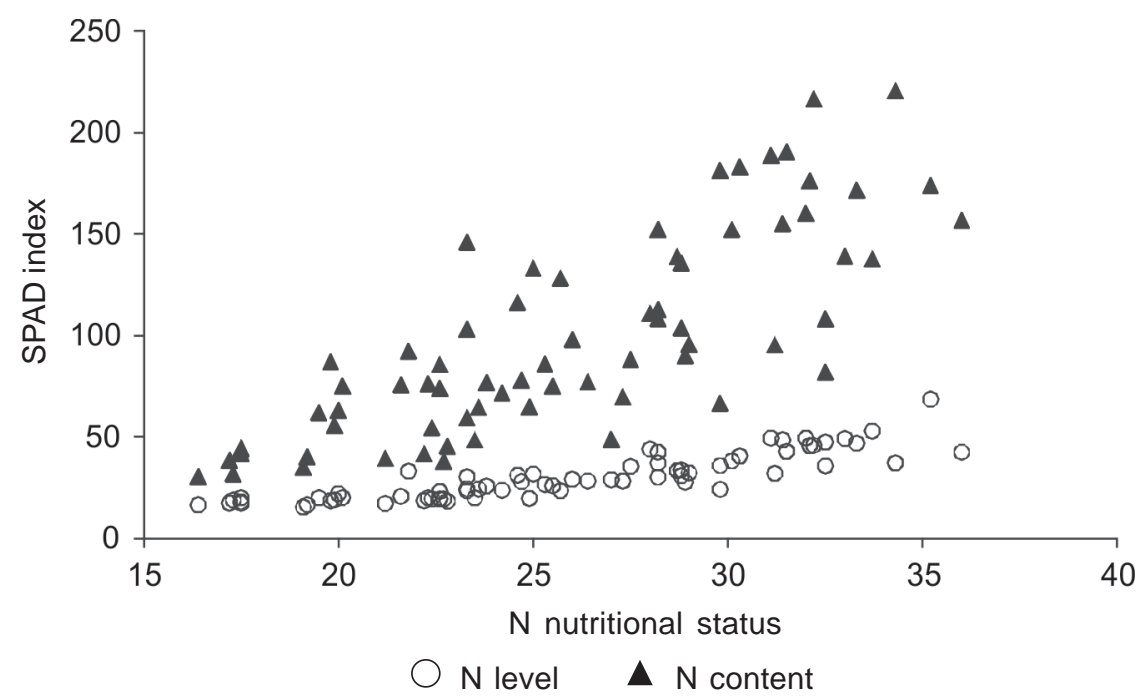

Figure 1. Linear correlation $(\mathrm{n}=70)$ between the nitrogen level $\left(\mathrm{g} \mathrm{kg}^{-1}\right)$ and content $(\mathrm{mg} / \mathrm{plant})$ and the SPAD index $\left(\mathrm{r}=0,87^{\mathrm{P}<0,01}\right.$ and $\mathrm{r}=0,79^{\mathrm{P}<0,01}$, respectively) from the aerial parts of maize plants.

\section{CONCLUSIONS}

The treatments containing N-fixing and P-solubilizing bacteria provided higher levels of these nutrients in maize leaves, as well as higher growth rates.

It was verified a synergistic effect of the vermicompost in combination with the bacteria on the maize plants, in the presence or absence of natural phosphate, promoting increases in the leaf contents of $\mathrm{N}$ and $\mathrm{P}$ as well as in the growth characteristics, which were superior to the application of bacteria only.

The use of rock phosphate with the bacterial inoculums, without the vermicompost, did not improve the bacterial inoculum.

The SPAD index increased with the bacterial inoculation and had a positive relationship with the levels and contents of $\mathrm{N}$ in the aerial part of maize plants.

\section{ACKNOWLEDGEMENTS}

We would like to thank Professor Pedro Henrique Monnerat (LFIT - UENF) for helping with the nutritional analyzes; Professor Messias Gonzaga Pereira (LMGV UENF) for kindly providing the maize seeds of the hybrid UENF 506-8; Dr. Jader Galba Busato (LSOL - UENF) for providing the Araxá rock phosphate; Dr. Fábio Bueno dos Reis Jr. (Embrapa Cerrados) for providing the HIII 206 strain of Herbaspirillum seropedicae; and FAPERJ, CNPq (Proc 470567/2011-2), FAPEMIG (APQ 02395-10, APQ - 0392910) and FUNARBE (FUNARPEC 2011) for the financial support.

\section{REFERENCES}

Alfoldi Z, Pinter L \& Feil B (1992) Accumulation and partitioning of biomass and soluble carbohydrates in maize seedlings as affected by source of nitrogen, nitrogen concentration and cultivar. Journal of Plant Nutrition, 15:2567-2583.

Rev. Ceres, Viçosa, v. 59, n.2, p. 262-270, mar/abr, 2012 
Alvarez VH \& Alvarez GAM (2006) Comparações de médias ou testes de hipóteses? Contrastes! Boletim Informativo da Sociedade Brasileira de Ciência do Solo, 31:24-34.

Baldotto LEB, Baldotto MA, Canellas LP, Smith, REB \& Olivares FL (2010a) Growth promotion of pineapple 'Vitória' by humic acids and Burkholderia spp. during acclimatization. Revista Brasileira de Ciência do Solo, 34:1593-1600.

Baldotto LEB, Baldotto MA, Viana AP, Olivares FL \& BressanSmith R (2010b) Seleção de bactérias promotoras de crescimento no abacaxizeiro (Ananas comosus L. Merril) cultivar vitória durante a aclimatização. Revista Brasileira de Ciência do Solo, 34:349-360.

Baldotto MA, Giro VB, Baldotto LEB, Canellas LP \& Velloso ACX (2011) Initial performance of pineapple and utilization of rock phosphate applied in combination with organic compounds to leaf axils. Revista Ceres, 58:393-401.

Braga JM \& De Filippo BV (1974) Determinação espectrofotométrica de fósforo em extratos de solos e plantas. Revista Ceres, 113:73-85.

Bucher CA \& Reis VM (2008) Biofertilizante contendo bactérias diazotróficas. (Documentos / Embrapa Agrobiologia, 247) Seropédica, Embrapa Agrobiologia, 17p.

Conceição PM, Vieira HD, Canellas LP, Marques JR RB \& Olivares, FL (2008) Recobrimento de sementes de milho com ácidos húmicos e bactérias diazotróficas endofíticas. Pesquisa Agropecuária Brasileira, 43:545-548.

De-Polly H, Almeida DL, Santos GA, Cunha LH, Freire LR, Amaral Sobrinho NMB, Pereira NNC, Eira PA, Bloise RN \& Salek RC (1988) Manual de adubação para o Estado do Rio de Janeiro, Itaguaí: Editora Universidade Rural, 179p.

Döbereiner J, Baldani VLD \& Baldani, JI (1995) Como isolar e identificar bactérias diazotróficas de plantas não-leguminosas. Seropédica, Embrapa Agrobiologia 66p.

Embrapa (1997) Manual de métodos de análise de solo. Rio de Janeiro, Centro Nacional de Pesquisa de Solos. 212p.

Girardini P, Tollennar M \& Muldon JF (1985) The effect of temporay $\mathrm{N}$ satarvation on leaf photosyntetic rate and chlorophil content of maize. Canadian Journal of Plant Science, 65:491-500.

Guimarães PTG, Fontes PCR, Pereira PRG, Alvarez VH \& Monnerat PH (1999) Teores de clorofila determinados por medidor portátil e sua relação com formas de nitrogênio em folha de tomateiro cultivados em dois tipos de solo. Bragantia, 58:209-216.
Kostov O \& Lynch JM (1998) Composted sawdust as a carrier for Bradyrhizobium, Rhizobium and Azospirillum in crop inoculation. World Journal of Microbiology \& Biotechnology, 14:389-397.

Liebich J, Schloter M, Schaffer A, Vereecken H \& Burauel P (2007) Degradation and humification of maize straw in soil microcosms inoculated with simple and complex microbial communities. European. Journal of Soil Science, 58:141-151.

Malavolta E (1980) Elementos de nutrição de plantas. São Paulo, Agronômica Ceres. 251p.

Marques Júnior RB, Canellas LP, Silva LG \& Olivares FL (2008) Promoção de enraizamento de microtoletes de cana-de-açúcar pelo uso conjunto de substâncias húmicas e bactérias diazotróficas endofíticas. Revista Brasileira de Ciência do Solo, 32:11211128.

Okon Y \& Labandera-Gonzalez CA (1994) Agronomic applications of Azospirillum: an evaluation of 20 years worldwide field inoculation. Soil Biology \& Biochemistry, 26:1591-1601.

Pooja-Suneja S, Dudeja S \& Narula N (2007) Development of multiple co-inoculants of different biofertilizers and their interaction with plants. Archives of Agronomy and Soil Science, $53: 221-230$

Rodriguez H \& Fraga R (1999) Phosphate solubilizing bacteria and their role in plant growth promotion. Biotechnology Advances, 17:319-339.

Salomone IG \& Döbereiner J (1996) Maize genotype effects on the response to Azospirillum inoculation. Biology and Fertility of Soils, 21:193-196.

Santos ST (2008) Biogeografia de bactérias culturáveis associadas às fruteiras tropicais. Tese de Doutorado. Universidade Estadual do Norte Fluminense Darcy Ribeiro, Campos dos Goytacazes, $105 \mathrm{p}$.

Silva Filho GN \& Vidor C (2000) Solubilização de fosfatos por microrganismos na presença de fontes de carbono. Revista Brasileira de Ciência do Solo, 24:311-319.

Vargas-García MC, Suárez-Estrella FF, López MJ \& Moreno J (2006) Influence of microbial inoculation and co-composting material on the evolution of humic-like substances during composting of horticultural wastes. Process Biochemistry, 41:1438-1443.

Vessey KJ (2003) Plant growth promoting rhizobacteria as biofertilizers. Plant Soil, 255:571-586. 